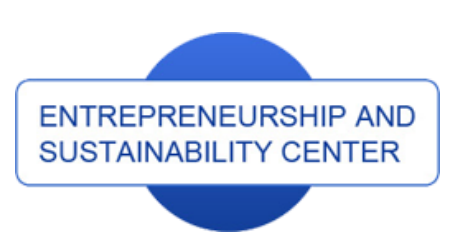

Publisher

http://jssidoi.org/esc/home

\section{enterprise}

europe

network

Business Support on Your Doorste

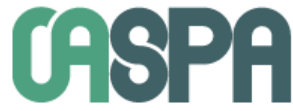

\title{
MARKETING AND BRANDING STRATEGY FOR THE SOUTH BALTIC SEA REGION: REINFORCING REGIONAL INNOVATION IN SMES THROUGH CROSS-BORDER COLLABORATION MODELS IN THE AGE OF TRANSFORMATION*
}

\author{
Laima Gerlitz ${ }^{1}$, Christopher Meyer ${ }^{2}$, Gunnar Prause ${ }^{3}$ \\ 1,2,3 University of Applied Sciences Wismar: Technology, Business and Design, Philipp-Müller-Str. 14, 23966 Wismar, \\ Germany \\ ${ }^{2,3}$ Tallinn University of Technology, Ehitajate tee 5, 19086 Tallinn, Estonia \\ E-mails: ${ }^{1}$ laima.gerlitz@hs-wismar.de; ${ }^{2}$ christopher.meyer@hs-wismar.de; ${ }^{3}$ gunnar.prause@hs-wismar.de
}

Received 10 January 2021; accepted 10 April 2021; published 30 June 2021

\begin{abstract}
South Baltic Sea Region (SBSR) is one of the EU cross-border regions that due to the patchy development patterns qualifies for EU financial support reinforcing innovation capacity and promoting collaborative and competitive mindset. Historically shaped by international collaboration patterns across the Baltic Sea, the SBSR turns into maritime or blue EU region. Being an integral part of the Baltic Sea Region (BSR) that has developed as role model for sustainable, green and smart region in the recent years, SBSR experiences increasing pace of change and the urge for sustainable transition. This creates a real conundrum for appropriate regional action. In this light, in the frame of the "InterMarE South Baltic" - a part-financed EU INTERREG project the researchers set out to contribute to situational improvement by developing tailor-made cooperative and region-wide Marketing and Banding Strategy for regional SMEs of all Blue Economy sectors. A
\end{abstract}

\footnotetext{
* This research was supported by the Interreg project "InterMarE South Baltic" project that was implemented in the frame of the Interreg South Baltic Programme 2014-2020 from July 2017 to Jun 2021. The project is based on the research and practical gaps highlighting the needs to support maritime SMEs in economic development by increasing their visibility under one joint regional brand.
}



\section{ENTREPRENEURSHIP AND SUSTAINABILITY ISSUES}

ISSN 2345-0282 (online) http://jssidoi.org/jesi/

2021 Volume 8 Number 4 (June)

http://doi.org/10.9770/jesi.2021.8.4(28)

joint macro-regional positioning strategy for the SBSR is highly missing and available strategic attempts can be traced back to joint marketing measures in the tourism sector only. Therefore, building on eclectic empirical data covering more than 130 surveyed SMEs from all participating countries - Denmark, Germany, Lithuania, Poland and Sweden, supported by expert interviews with representatives of Blue Economy sectors in the SBSR and BSR, direct observations and field research done in the frame of study visits outside the region, this treatise presents an innovative, integrative and topical cooperative model for joint cross-border marketing and branding of SMEs operating in the SBSR in all applicable Blue Economy sectors.

Keywords: marketing strategy; regional branding; branding strategy; South Baltic Sea Region; Blue Economy; regional innovation; SMEs

Reference to this paper should be made as follows: Gerlitz, L. \& Meyer, C., Prause, G. 2021. Marketing and Branding Strategy for the South Baltic Sea Region: Reinforcing Regional Innovation in SMEs through Cross-Border Collaboration Models in the Age of Transformation. Entrepreneurship and Sustainability Issues, 8(4), 467-487. http://doi.org/10.9770/jesi.2021.8.4(28)

JEL Classifications: M31, R11, O31, O41

\section{Introduction}

Sustainable and smart development in the European Union (EU) is at the epicentre of all policy discourses. Applicable innovation and growth policies are key to achieve innovation. In the EU, innovation is highly policydriven. New EU Industrial Policy based on circular economy principles and the European Green Deal (EGD) as the New EU Growth Strategy serve as key roadmaps. In this sense, all industry sectors and businesses, in particular, Blue Economy, will need to focus in the next future on achieving good environmental and digital status on local, regional and international level, thus also contributing to the Sustainable Development Goals (SDGs) of the United Nations. However, sustainable transition in peripheral regions and remote areas of the EU, bearing in mind their poorer innovation performance and lower industrial power due to scarcity of human, financial or natural resources, low integration and exchange with outstanding regions or increasing macro-regional competitive pressure as well as decreasing cognitive, organisational and social proximity jeopardise the desired development avenues, as set in the recent EU policy agendas.

In this light, South Baltic Sea Region (SBSR) which is the geographical focus of the present research yields patchy development patterns, when it comes to innovation performance (Regional Innovation Scoreboard 2019). Building upon recent available data from 2019 benchmarking of all EU NUTS-2 level regions and comparing regional innovation performance of corresponding regions that belong to the SBSR - Denmark, Germany, Lithuania, Poland and Sweden - remarkable differences can be observed, having Strong Innovators - Danish, German and Swedish SBSR regions one the one hand and Moderate Innovators - Lithuanian regions, followed by Modest Innovators Polish regions with the lowest innovation capacity. Similar insights were made applying EU Member States' ecoinnovation index showing countries' performance in sustainability. The overview of the eco-innovation performance in 2019 yields great disparities among countries like Denmark ( $2^{\text {nd }}$ rank in the EU), Sweden $\left(4^{\text {th }}\right.$ rank), Germany ( $6^{\text {th }}$ rank), Lithuania (19 $9^{\text {th }}$ rank) and Poland (25 ${ }^{\text {th }}$ rank) (Eco-Innovation, Country Profiles, 2019).

Finally, a light on the macro-regional perspective - the entire Baltic Sea Region (BSR) with all the Baltic Sea surrounding countries, SBSR being a part of this macro-region, delivers rather a more exacerbated view on current and future development prospects. On the one hand, SBSR has huge opportunities to learn from the BSR achievements, as the BSR has established itself as a role model for sustainable, green and smart region in the recent years. On the other hand, better competitive position of the BSR and its recognition among other macro-regions might make accessibility and recognition of smaller cross-border region, like SBSR is, more difficult (Philipp et al., 2020). 


\section{ENTREPRENEURSHIP AND SUSTAINABILITY ISSUES}

ISSN 2345-0282 (online) http://jssidoi.org/jesi/

2021 Volume 8 Number 4 (June)

http://doi.org/10.9770/jesi.2021.8.4(28)

Overall, the most prevailing challenges in all SBSR countries refer to process-level of innovation, i.e. missing resources efficiency, delivery of sustainable products including missing green investments and R\&D personnel available. This makes clear that regional policy makers, knowledge developers and SMEs as regional economy drivers should therefore reinforce internal organisational capacity building in terms of greening (sustainable development) processes and organisational performance on human, product, materials and environmental level, leading to sustainable innovations. In turn, sustainable innovations open up avenues for sustainable growth and increase in competitive advantage. Against this background of presented data, it is crucial to focus on and enhance knowledge transfer as well as capacity building using new tools, establish on-going actions, reinforce conceptualisation and capitalisation on Blue Growth initiatives and incentives as well as to implement joint regional and macro-regional actions supporting regional economy growth and regional development.

In this light, back in 2017, the EU approved the "InterMarE South Baltic - Internationalisation of South Baltic Maritime Economy" project, which is part-financed by the South Baltic Programme 2014-2020. Historically shaped by international collaboration patterns tracing back to the Hanseatic trading era that emerged using natural cooperation platform - the Baltic Sea - SBSR developed into one cross-border maritime region with similar regional identity, social, economic and geographical setting. Considering peripheral regional positioning and aiming to counteract the ailing situation of the region as briefly depicted above, thus contributing to rich natural marine (blue) resources conservation pooled within and around the Baltic Sea, the project aims at reducing regional bottlenecks in terms of lower innovation capacity of SMEs, enhancing better cross-border cooperation through joint cooperative marketing and branding activities and institutionalising new collaboration models as an InterMarE South Baltic blue network and cluster service brand, which is mainly dedicated to service regional SMEs and underpin their marketing and internationalisation capacity over the regional boundaries.

Respectively, within the time frame of 07/2017-06/2021, the research team lead by researchers and academic experts of Hochschule Wismar, University of Applied Sciences acting as research leading partner within the InterMarE South Baltic project consortium, and supported by academic peers from Lithuania, undertook a series of research steps that allowed to arrive at a tailor-made cooperative and region-wide Marketing and Branding Strategy for regional SMEs of all Blue Economy sectors in the SBSR. As a result, the present research depicts key building pillars of the developed Marketing and Branding Strategy dedicated to regional Small and Medium-Sized Enterprises (SMEs) including freelancers and start-ups from the Blue Economy and argues how it can be practically and step-by-step deployed by regional SMEs, academic and research experts and well as within policy discourses that are responsible for shaping and stipulating next future Regional Innovation Strategies (RIS).

The principle idea behind the delivered strategy is to make regional businesses explicit how they can practically improve their marketing and internationalisation capacity including principle responsive and sustainable actions. This research impetus derives from the observed needs of regional SMEs and other actors to "translate" and "decode" Blue Economy policy into business language as well as to strengthen regional SMEs that are operating in times of urgent transformation, increasing complexity and blurring development projection in their innovation capacity improvement, thus paving the way for regional growth and regional development, respectively. In this sense, the research raised the following research question:

How can blue SMEs of the South Baltic Sea Region be supported in their marketing and branding activities enabling sustainable growth of the Blue Economy?

Bearing the formulated question in mind, the research in hands aims at reducing the science-to-practice research gap: in the SBSR there could not be located any specific Blue Economy concerning marketing strategy. Browsing of the resource pool, there was located only one marketing strategy that pinpoint the export of Small and MediumSized Enterprises (SMEs) in the region (Treder \& Kulawczuk, 2012). Yet, this study shows specific export related marketing strategies for individual businesses and organisations. Further similar sources found only touch upon the 


\section{ENTREPRENEURSHIP AND SUSTAINABILITY ISSUES}

ISSN 2345-0282 (online) http://jssidoi.org/jesi/

2021 Volume 8 Number 4 (June)

http://doi.org/10.9770/jesi.2021.8.4(28)

issue of the marketing slightly, by paying attention mainly to tourism sector, e.g. destination and marine $\&$ coastal tourism (Hacia \& Lapko, 2017; Lapko \& Müller, 2018; Manniche, et al., 2017; Nilsson et al., 2010; Swacha et al., 2018) or food and agriculture related marketing (Olsson, 2015; Petrenko et al., 2014). In addition, the present research aims at strengthening Blue Growth research by linking nature and society paradigms, thus bringing back social science perspective into the discourse (Arbo et al., 2018, p. 296; Ertör \& Hadjimichael, 2020, p. 8).

The present paper is organised in the following way: the next chapter positions SBSR within theoretical and placedbased nexus and is followed by methodological considerations. In the succeeding chapter, the Marketing and Branding Strategy is presented. Discussion and conclusions' chapter positions research results within theoretical and managerial contributions and provides future research avenues.

\section{Need for Marketing and Branding within the Regional Setting: Theoretical and Practical Considerations}

SBSR's identity is much more than only tourism or food destination. The access to the Baltic Sea and marine resources brings more potential to be fertilised. As the Blue Growth Strategy of the European Commission (EC) $\operatorname{COM}(2012) 0494$ final and related policies highlight, e.g. Report on the Blue Growth Strategy SWD(2017) 128 final or European Green Deal COM(2019a) 640 final, there are further value adding sectors and areas within the established and emerging industries that build up the EU Blue Economy (EC, 2018), in particular when it comes to investment incentives for SMEs contributing towards Blue Economy growth, e.g. aquaculture, renewable energy, seabed mining etc.

Reflecting upon the bigger counterpart - Baltic Sea Region (BSR) - it has so far achieved better recognition on international and global level, by addressing e.g. tourism related and place branding or regional identity building issues (Andersson, 2007; Routes 4U, 2017; Policy Area Tourism of the EU Strategy for the Baltic Sea Region, 2016). Indeed, the BSR is recognised as a strong touristic destination. Furthermore, strategic positioning of the BSR is underpinned through the EU Strategy for the Baltic Sea Region (EUSBSR) and EUSBSR Action Plan 2020, as approved by the National Coordinators Group in 2020 and by the European Commission in 2021 (EC, 2021). Yet, within the BSR ecosystem and without specific place-based marketing and branding, the SBSR is not capable to differentiate itself from the macro-region, which already has done work in place branding.

SBSR frames an integral part of the bigger counterpart macro-region, the BSR. As it is claimed in policy and research discourses, the BSR has sustained its competitive position over the last years among other macro-regions in terms of sustainable marine-driven development and therefore is coined as a flagship marine region in Europe with prevalent good economic, social and environmental performance indicators (Gerlitz et al., 2017; Ketels \& Pedersen, 2016; Metzger \& Schmit, 2012; Stiller \& Wedemeier, 2012; Vitola, 2015). It is therefore clear that SBSR also takes a stake of this outstanding performance. Following the latest issue of the "State of the Region Report" (Ketels et al., 2017), the BSR generated in 2015 an annual GDP of about 2.000 billion EUR, which is equivalent to $12.5 \%$ of the EU-28 economy. The performance strength is linked with outputs in two key clusters; a) forestry, furniture and fishing; and b) water transportation including oil and gas and metal mining.

Against this background, the "InterMarE South Baltic" goes a step further and aims at designing the network and cluster-based brand with its strategy that promotes the region with its strong Blue Economy performance instead of individual businesses. Indeed, the scientific community acknowledges that clustering and networking presupposes better recognition and market penetration opportunities (Costa \& Verissimo, 2020). Furthermore, it is highlighted in the literature that networks and clusters should put in place not only marketing, but also branding, which is again crucial for the cross-border regional development (Alberti et al., 2016; Knippschild, 2011, Pasquinelli, 2013). 


\section{ENTREPRENEURSHIP AND SUSTAINABILITY ISSUES}

ISSN 2345-0282 (online) http://jssidoi.org/jesi/

2021 Volume 8 Number 4 (June)

http://doi.org/10.9770/jesi.2021.8.4(28)

This is highly relevant for the SBSR, which is rather small region in the macro-regional perspective. For this, building up strong institutional framework, involving stakeholders, formulating shared goals and thus delivering the value is at the core of the concerned initiative and the strategy. A shared vision with shared goals is crucial for success in marketing and branding, as one cluster and network organisation such as "InterMarE South Baltic" is a necessity for strategy implementation, joint brand image generation and common brand identity. By echoing Hess (2011), the main effort remains of synchronising individual marketing efforts of sub-regions and nations in order to develop common understanding followed by joint marketing and branding actions (p. 83). As a result, the present work aims also at reducing both research and policy gaps in delivering Marketing and Branding Strategy for the SBSR Blue Economy Growth that builds upon interdisciplinary theoretical approaches addressing wider societal relations and territorial perspectives (Andersson, 2014, p. 151).

When it comes to the geographical place-based positioning, marketing and branding aims at supporting cohesion and economic development within the regional setting, i.e. cross-border region SBSR, whereby the region is referred to as more or less bounded area possessing some sort of unity or organising principles that distinguish it from other regions (Johnston, 2000, p. 687), as a territorially determined unit differing from its surroundings and possessing some form of identity (Tägil, 1983, p. 18). Next to the territorial categorisation, social perception plays in the given context a crucial role, since the present study deals with marketing and branding, which found their conceptual meanings in the social domain of interactions. Indeed, thee recent research purports that building upon relations and gaining relationship values through relationship-specific investments, knowledge sharing, relational norms, marketing capabilities can be improved. Furthermore, cultural sensitivity reduced social and organisation distance (Jean et al., 2010; Lee et al., 2008; Skarmeas et al., 2016). Finally, creativity, open innovation support businesses in innovation and opens up new avenues for growth (Hack et al., 2012).

As a result, the region, and thus the SBSR is determined via social dimension maintaining relations between people, nature and society within the scope of regional formation, underpinned by cultural dimension pinpointing region as an identity of cultural relationships between a group and respective places as well as underpinned by awareness of common cultural similarities among the regional population, e.g. historical trade routes (amber trading) across the SBSR or participation in the Hanseatic League. As a result, marketing and branding of the region concerns interactions and practices reflected through political, economic, cultural administrative, institutional and power relations (Paasi, 2001, p. 16), reinforced by networks, practices and processes spanning beyond the borders of the region (Paasi, 2009, p. 467). Finally, the SBSR stands for a region within the European dimension, a cross-border region, facilitating cohesion and integration of the EU through gathered together administrative territorial units of the Member States of the EU determined on the basis of NUTS classification as individual NUTS-2 regions.

Through intensifying globalisation and arising global networks, new social and environmental challenges jeopardise innovation and growth opportunities in different markets. Indeed, this is especially true for the SME sector and the performance of individual regions in the EU (Prause et al. 2018). Following the European Commission (2018a), more than $99 \%$ of all companies in the EU represent micro and SMEs. In 2018, nearly 25 million SMEs in the EU28 generated about $56.4 \%$ of value added and $66.6 \%$ employment in the Non-Financial Business Sector (NFBS). Therefore, SMEs are regarded as the backbone and driver of regional and national economies. Thus, there is a need to support SMEs and entrepreneurship, since they have a crucial role in generating economic growth, triggering innovations, attracting new investments and businesses, enabling clusters to evolve, ensuring employability and social integration (Prause et al., 2018; EC, 2019c, 2013a, 2013b). 


\section{ENTREPRENEURSHIP AND SUSTAINABILITY ISSUES}

ISSN 2345-0282 (online) http://jssidoi.org/jesi/

2021 Volume 8 Number 4 (June)

http://doi.org/10.9770/jesi.2021.8.4(28)

Here, SMEs will need to find new ways of operation through the lens of the European Green Deal, in particular, Regional Innovation on Smart Specialisation (RIS3) concepts' utilisation (EC, 2020b; Gerlitz et al., 2020). In this particular context, marketing strategy might serve as a source of innovation and thus competitive strength, since the research contends that marketing formulation and implementation has positive effects SMEs innovativeness performance (Finoti et al., 2017). Vice versa, innovation has a positive effect on marketing performance (Afriyie \& Musah, 2019). SMEs are regarded as accelerators for innovative products and services of high quality. Yet, in the EU main challenges refer to low SMEs capacity in services' sector and low exports of EU SMEs. in addition, external financing incentives and venture capital investments should be put on the SME development priority lists.

Next to the SME size and performance related obstacles, key future challenges will be circled around missing capacity and capabilities in environmental and digital transition, regional, EU and international policy compliance as well as burning needs to reduce negative footprints in societal, environmental, governance and economic performance domains. New EU Industrial Policy based on circular economy principles and the European Green Deal (EGD) as the New EU Growth Strategy serve as key roadmaps. Future port business will need to focus on transformation by twinning environmental and digital goals. By doing this, it is believed here, a sustainable socioeconomic growth can be grounding, simultaneously benefiting business and society, i.e. providing growth opportunities for businesses and meeting needs and expectations of more environmentally conscious society.

In particular, regional SMEs, policy makers and researchers will need to focus in the next future simultaneously on sustainable development, growth and competitiveness by considering compliance with and contribution to the 17 SDGs of the UN. By now, BSR countries are well on the global level in terms of overall SDG performance, but face challenges in implementation of the 2030 Agenda in most of the SDGs (Beyersdorff \& Lanthen, 2018, p. 12; OECD, 2019, p. 12). Specifically, the future actions in the BSR will need to focus on SDG 9 (Industry, Innovation and Infrastructure), SDG 11 (Sustainable Cities and Communities); SDG 12 (Responsible Consumption \& Production), SDG 13 (Climate Action) and SDG 15 (Life on Land). The major challenges are to be expected in the implementation of the SDG12 and SDG 13, since in these two areas all BSR countries perform bad (ibid., p. 12).

In this vein, more potential and proactive approach is needed, increase in cooperation, multi-sectoral and holistic engagement (Ahlgren, 2019, p. 2; Böhme et al., 2016, p. 4; EC, 2021). A special emphasis will be needed for a circular economy, green technology sophistication, increase of ecological footprint (Borges \& Topsiduo, 2020, p. 7) as well as green sense making among local policy-makers in terms of sustainable place-based development (Andersson, 2016, p. 1197

\section{Methodology}

The present research focuses in Blue Economy sectors in the SBSR. Here, established and emerging sectors are considered to be core and driving forces of the Blue Growth in the region and in the entire EU. Therefore, research was conducted with participation of the following target groups: 
Table 1. Focused Blue Economy Sectors / Industries

\begin{tabular}{|c|c|c|}
\hline \multicolumn{2}{|c|}{ Established Sectors } & Emerging Sectors \\
\hline 11 & $\begin{array}{l}\text { Coastal tourism } \\
\text { - Hotels and accommodation } \\
\text { - Recreation infrastructure and } \\
\text { actors } \\
\text { - Mobility and transportation }\end{array}$ & $\begin{aligned} & \text { Blue biotechnology } \\
& \text { : } \text { Biofuels (algae) } \\
& \text { - } \text { Pharmaceuticals, chemicals } \\
& \text { - } \text { Health } \\
& \text { - } \text { Genetics }\end{aligned}$ \\
\hline & $\begin{array}{l}\text { Marine living resources } \\
\text { - Aquaculture } \\
\text { Processing, retail and wholesale } \\
\text { of fish, crustaceans and molluscs } \\
\text { Extraction of marine living } \\
\text { resources }\end{array}$ & $\begin{array}{c}\text { Coastal and environmental protection } \\
\text { - Carbon capture and storage } \\
\text { - Coastal and habitat protection }\end{array}$ \\
\hline & $\begin{array}{l}\text { Marine transport } \\
\text { - Sea and coastal passenger water } \\
\text { transport } \\
\text { - Sea and coastal freight water } \\
\text { transport } \\
\text { - Inland passenger water transport } \\
\text { - Inland freight water transport } \\
\text { Renting and leasing of water } \\
\text { transport equipment }\end{array}$ & $\begin{array}{l}\text { Desalination } \\
\text { - Fresh water supply } \\
\text { Marine defence and security } \\
\text { - Marine surveillance }\end{array}$ \\
\hline & $\begin{array}{cl}\text { Offshore oil and gas } \\
\text { - } & \text { Extraction of crude petroleum } \\
\text { - } & \text { Extraction of natural gas } \\
\text { - } & \text { Extraction support activities }\end{array}$ & Marine research and education \\
\hline & $\begin{array}{l}\text { Port activities } \\
\text { - Cargo handling } \\
\text { - } \text { Warehousing and storage } \\
\text { - Water transportation related } \\
\text { activities }\end{array}$ & $\begin{array}{l}\text { Ocean energy } \\
\text { - Offshore wind } \\
\text { - Ocean wave and tidal energy } \\
\text { Submarine cables }\end{array}$ \\
\hline 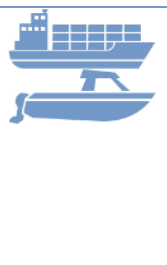 & 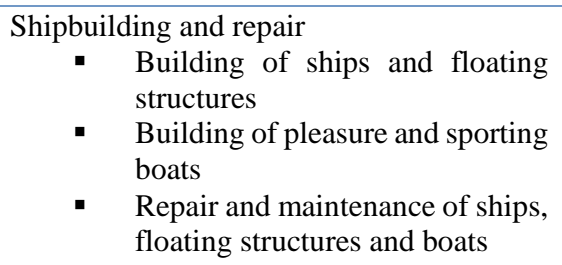 & $\begin{array}{l}\text { Seabed mining } \\
\text { - } \text { Aggregates } \\
\text { - } \quad \text { Marine minerals }\end{array}$ \\
\hline
\end{tabular}

Source: Compiled by authors 


\section{ENTREPRENEURSHIP AND SUSTAINABILITY ISSUES}

ISSN 2345-0282 (online) http://jssidoi.org/jesi/

2021 Volume 8 Number 4 (June)

http://doi.org/10.9770/jesi.2021.8.4(28)

Overall, the present research utilises the case study methodology by combining theoretical considerations of Merriam (2008) and Yin (2018). First, it is because the focus of the research is on social constructs. Therefore, we combine quantitative and qualitative data, thus supporting Yin's conception, while we also consider social aspects and perception of a case as a specific institution or a socially determined construct as important aspects in the face of the target groups - regional SMEs. The aggregated research trajectory can be summarised in the following way:

- Research scope:

- Geographical coverage:

- Research scale:

- Research time lapse.

- Research approach:

- Research methods:

- Research data:

- Research techniques:

- Research validation:
Interreg VA project InterMarE South Baltic.

South Baltic Sea Region - Danish, German, Lithuanian, Polish and Swedish Spain (Valencia), South Korea (Busan), United Kingdom (London), Norway (Oslo), the Netherlands (Amsterdam) around 130 surveyed SMEs from the SBSR 07/2017-12/2020

inductive survey, expert interviews, study visit reports quantitative and qualitative data analysis, explanation building external validity by SBSR SMEs; maritime experts evaluation

Wrapping up the research journey we claim that we underpin the qualitative research methodology by integrating the so-called actor's approach (Arbnor \& Bjerke, 2008). The research deals with reality and real challenges of SMEs addressed within the applied research project. The reality is socially constructed including and integrating stakeholders, participating and constructing sense-making and understanding (Creswell, 2013; Lincoln et al., 2011). This reality is constructed by a number of meanings that are shared by a larger and small number of people (Arbnor and Bjerke, 2008, p. 66). Indeed, understanding of the observed and analysed reality as a social construct lends a strength to the present research. In this regard, employing the actor approach is argue to be feasible and beneficial both to science and management practice.

In sum, the researchers disclosed their bias through the participation in the project as leading researchers and encountered this through involvement of experts in validation of the results as well as presentation of the intermediate results to direct target groups - regional SMEs - to get their feedback on marketing and branding strategy's value added and transferability.

\section{Regional Marketing and Branding Strategy and Its Managerial Implications}

SMEs are regarded as backbone and drivers of regional and national economies. Therefore, there is a need to support SMEs and entrepreneurship, since they have a crucial role in generating economic growth, triggering innovations, attracting new investments and businesses, enabling clusters to evolve, ensuring employability and social integration. Hence, SMEs are regarded as accelerators for innovative products and services of high quality. Having analysed SBSR past successes, understood current challenges and projected future bottlenecks and potentials, for strategists, it is essential to know main players and key performance influencing factors within the SBSR ecosystem and beyond its boundaries. To meet growing requirements to parse volatility, complexity and ambiguity of interactions, the developed SBSR Marketing and Branding Strategy, as depicted below, can help out regional businesses, planners, governance bodies, decision makers, regional managers and other strategists to easier navigate within Blue Economy innovation and promotion 


\section{ENTREPRENEURSHIP AND SUSTAINABILITY ISSUES}

ISSN 2345-0282 (online) http://jssidoi.org/jesi/

2021 Volume 8 Number 4 (June)

http://doi.org/10.9770/jesi.2021.8.4(28)

\subsection{Marketing and Branding SBSR as A strong Blue Resource and Competence Cluster}

The InterMarE South Baltic brand as a networking and cluster service for blue economies serves as facilitator of businesses and adjusts their individual activities to innovation policies. Thus, the cluster aims at supporting individual blue SMEs by offering knowledge, experiences, contacts and consultancy to strategically match daily business with European, national and regional policies with focus on the Blue Economy. Hence, it is not the objective to tell companies how to further develop their business in detail, but to provide several insights of Growth Strategies, which should be adapted to individual company demands.

Table 2 introduces some key facts to be fuelled into business by maritime SMEs when considering Blue Economy development and resources' allocation to daily business. The three columns indicate necessary topics to be addressed when developing any business strategies in line with Blue Economy: Resources \& Capabilities, Innovation \& Strategy and Sustainable Organisation Ecosystem. Furthermore, the matrix provides some key facts or insights, which represent each category and should be reflected in business strategies or at least be discussed and analysed internally, e.g. branding activities on company level to create and establish InterMarE South Baltic network and cluster. In addition, a differentiation of short- and long-term is offered on a quite general level at this stage. The short-term recommendations mainly refer to identification of own potentials for future development as well as analysing the state of the art for the own business. In the long-term, new technologies and sustainable mechanisms have to be incorporated to the company ecosystem.

Table 2. SBSR Marketing and Branding through Resource Pooling and Innovation

\begin{tabular}{|c|c|c|}
\hline $\begin{array}{l}\text { 1. Build up Your Resources \& Capabilities } \\
\text { for Smart and Sustainable Blue Economy }\end{array}$ & $\begin{array}{l}\text { 2. Engage into Blue Economy } \\
\text { Innovation \& Strategy Exploitation }\end{array}$ & $\begin{array}{l}\text { 3. Capitalise on Blue Economy } \\
\text { from Branding \& Engagement in } \\
\text { Sustainable Organisation } \\
\text { Ecosystem }\end{array}$ \\
\hline $\begin{array}{l}\text { Mobilise your Competitive Resources and } \\
\text { Core Competences essential in meeting } \\
\text { growing demands for sustainable and smart } \\
\text { Blue Economy in the following areas: } \\
\text { Human Capital - increase interactions } \\
\text { and collaboration, since SBSR is } \\
\text { peripheral and rural areas' comprising } \\
\text { region, thus making joint action as a } \\
\text { strength } \\
\text { Social Capital - improve your } \\
\text { empathy and understanding of } \\
\text { ecosystem and systematic cognition - } \\
\text { ecological, economic, financial, } \\
\text { institutional; remember that } \\
\text { customers / users play crucial role for } \\
\text { your success and / or failure through } \\
\text { trust, positive experience, shared } \\
\text { values } \\
\text { Knowledge Capital - develop future } \\
\text { skills in analytics, innovation, } \\
\text { problem solving, Big Data, IoT, } \\
\text { micro-electronics, batteries, cyber- } \\
\text { security, STEM subjects, critical } \\
\text { thinking and creativity; invest in } \\
\text { resilience for uncertain futures; know } \\
\text { Sustainable Development Goals }\end{array}$ & $\begin{array}{l}\text { Know and consider key future trends } \\
\text { \& emerging markets: } \\
\text { Clean Technologies in } \\
\text { production, transport \& } \\
\text { logistics, consumption (food, } \\
\text { textiles, clothing), tourism, } \\
\text { space and automotive } \\
\text { Resource Efficiency related } \\
\text { technologies eco-design } \\
\text { production, re-use and recycle } \\
\text { (waste-to-energy) } \\
\text { Digital Transformation } \\
\text { (hardware, software, e- } \\
\text { commerce, wireless services, } \\
\text { online banking, Blockchain) } \\
\text { Mobility technologies } \\
\text { (waterborne freight } \\
\text { transportation and passenger } \\
\text { mobility) } \\
\text { Environmental Industries } \\
\text { Utilise strength of industry cluster } \\
\text { within and beyond the region and } \\
\text { engage into them - EU Cluster } \\
\text { Mapping Tool, EU Regional } \\
\text { Ecosystem Scoreboard }\end{array}$ & $\begin{array}{l}\text { Build up your Competitive } \\
\text { Advantages by means of: } \\
\text { value creation - use the } \\
\text { addressed key future } \\
\text { funding areas, trends and } \\
\text { markets } \\
\text { become a game changer } \\
\text { through deployment of } \\
\text { Smart Specialisation } \\
\text { principles and } \\
\text { contribution to Regional } \\
\text { Innovation Strategy (RIS) } \\
\text { claim and prove your } \\
\text { contribution to the } \\
\text { European Green Deal } \\
\text { claim your contribution to } \\
\text { the SDGs and } \\
\text { Agenda2030 } \\
\text { Join InterMarE South Baltic } \\
\text { Brand by: } \\
\text { Joining the network } \\
\text { through the database on } \\
\text { intermare-southbaltic.eu } \\
\text { Join events, exhibitions } \\
\text { and trade fairs organised } \\
\text { or promoted by the }\end{array}$ \\
\hline
\end{tabular}


ENTREPRENEURSHIP AND SUSTAINABILITY ISSUES

ISSN 2345-0282 (online) http://jssidoi.org/jesi/

2021 Volume 8 Number 4 (June)

http://doi.org/10.9770/jesi.2021.8.4(28)

\begin{tabular}{|c|c|c|}
\hline $\begin{array}{l}\text { 1. Build up Your Resources \& Capabilities } \\
\text { for Smart and Sustainable Blue Economy }\end{array}$ & $\begin{array}{l}\text { 2. Engage into Blue Economy } \\
\text { Innovation \& Strategy Exploitation }\end{array}$ & $\begin{array}{l}\text { 3. Capitalise on Blue Economy } \\
\text { from Branding \& Engagement in } \\
\text { Sustainable Organisation } \\
\text { Ecosystem }\end{array}$ \\
\hline 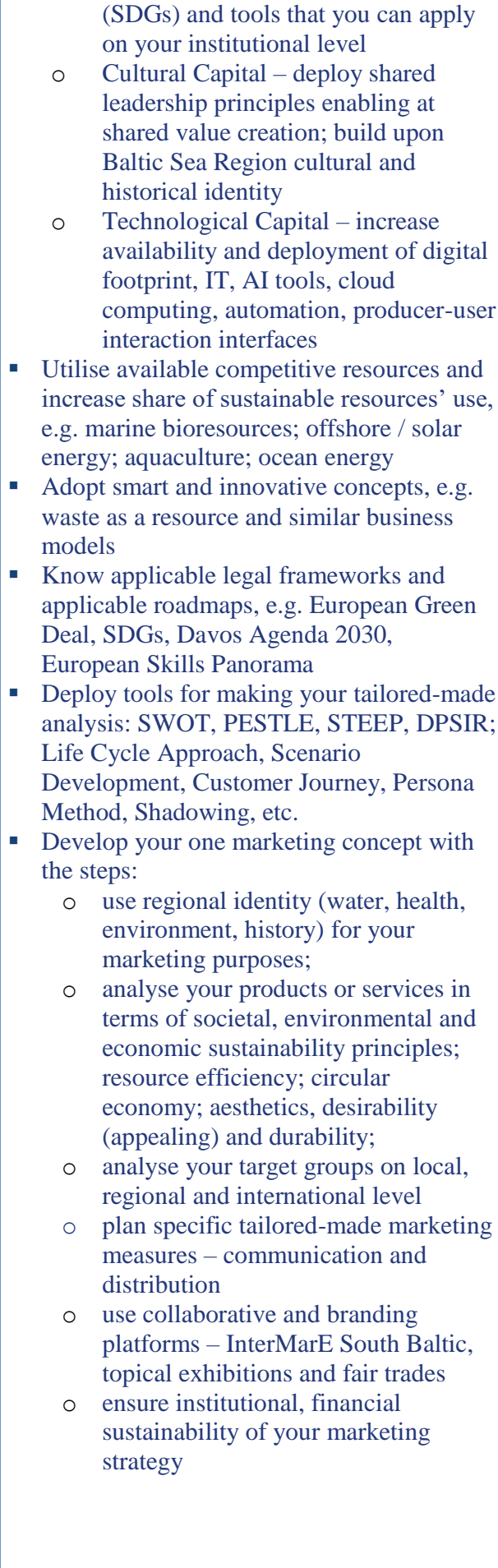 & $\begin{array}{l}\text { - Innovative through learning - } \\
\text { benchmark yourself against others in } \\
\text { terms of productivity, innovativeness, } \\
\text { social, economic and environmental } \\
\text { sustainability, digitalisation, } \\
\text { governance and leadership } \\
\text { Engage into innovation-driven or } \\
\text { accelerating processes: } \\
\text { Investments / Funds - use EU, } \\
\text { national and local investments } \\
\text { and incentives supporting your } \\
\text { environmental and digital } \\
\text { transition, e.g. EU Innovation } \\
\text { Fund, Just Transition Fund, } \\
\text { New European Bauhaus } \\
\text { Initiative, Horizon Europe } \\
\text { Programme, EU Structural and } \\
\text { Regional Funds } \\
\text { Economic efficiency - design } \\
\text { sustainable business models } \\
\text { benefitting the entire ecosystem } \\
\text { Capacity Building - remember } \\
\text { that EU sets out to support } \\
\text { Europe's twinning lighthouses / } \\
\text { leaders - green and digital } \\
\text { transition going hand in hand } \\
\text { Boost and make use of cross-border } \\
\text { cooperation: } \\
\text { Exchange knowledge through } \\
\text { projects, events and resources } \\
\text { that are free of charge, thus } \\
\text { saving own resources, but } \\
\text { building networking, knowledge } \\
\text { capacity } \\
\text { Learn on and from best } \\
\text { projects you need to implement } \\
\text { through engagement in topical } \\
\text { cotworks or finding your local } \\
\text { Europt points, e.g. Enterprise } \\
\text { leaders in the region (Sweden, } \\
\text { Contact Points } \\
\text { Denmark, Finland) through } \\
\text { cooperation across borders } \\
\text { Create synergies that enable } \\
\text { boosting your performance and } \\
\text { marketing activities - joint } \\
\text { market performance and } \\
\text { penetration, public awareness } \\
\text { - solidarity in the region } \\
\text { - }\end{array}$ & $\begin{array}{l}\text { InterMarE South Baltic } \\
\text { brand and network } \\
\text { Get revenues from the } \\
\text { joint commercial activities } \\
\text { (promotion campaigns) } \\
\text { through placement on } \\
\text { your logo on the } \\
\text { InterMarE South Baltic } \\
\text { brand and network } \\
\text { Reduce your investment } \\
\text { costs for marketing and } \\
\text { branding activities } \\
\text { through InterMarE South } \\
\text { Baltic brand and network } \\
\text { standing for maritime } \\
\text { cluster, as clusters have } \\
\text { proven higher productivity } \\
\text { Increase your visibility } \\
\text { and attractiveness by } \\
\text { joining the InterMarE } \\
\text { South Baltic brand and } \\
\text { network - maritime SMEs } \\
\text { are dispersed and bound } \\
\text { mainly to periphery of } \\
\text { economic interactions } \\
\text { Improve orientation, } \\
\text { facilitate reliability and } \\
\text { decision making }\end{array}$ \\
\hline
\end{tabular}




\section{ENTREPRENEURSHIP AND SUSTAINABILITY ISSUES}

ISSN 2345-0282 (online) http://jssidoi.org/jesi/

2021 Volume 8 Number 4 (June)

http://doi.org/10.9770/jesi.2021.8.4(28)



Source. Compiled by authors.

In order to capitalise from new knowledge and skills as well as increase deployment of improved capacity on the SME level, SMEs should be aware of available sources on the EU and international level that would grant not only access to information and knowledge about responsible innovation spurring institutions, innovation governance patterns, but also provide entrance to tools of benchmarking, databases and sites of innovation funding. Preliminary the most important institutions on the EU level facilitating innovation performance measurement and future foresight are the following:

- European Innovation Scoreboard / Regional Innovation Scoreboard

- Regional Innovation Monitor Plus

- KETs Observatory

- Virtual Tourism Observatory

- European Cluster Collaboration Platform

- COSME Programme

- Horizon 2020 / Horizon Europe

- European Structural and Investment Funds

- European Investment Bank and European Investment Fund

- SDG Index and Dashboard.

All above listed institutions facilitate responsible innovation development, access to innovation funding and support for innovation. They can be used as initial stepping stone for SMEs in order to start they search and resources' pooling. As a result, the project proposes the InterMarE South Baltic Marketing and Branding Strategy, which follows the rational incentive in, first, utilising existing and or building up new resources, competencies and capacities that will be in high demand in the next future.

\subsection{Marketing and Branding SBSR as A Learning Region with Entrepreneurial Discovery and Smart Specialisation}

In order to capitalise from gathered knowledge, built up competencies and capacities as well as to engage into entrepreneurial discovery process, which, in turn, follows combination and integration of knowledge from different domains and under inclusion of different across academia \& research, policy makers, businesses and society at large, SMEs are given sound capabilities to engage into innovation - creation and discovery process. Another crucial policy approach, which needs to be implemented on business level as well is Smart Specialisation or 


\section{ENTREPRENEURSHIP AND SUSTAINABILITY ISSUES}

ISSN 2345-0282 (online) http://jssidoi.org/jesi/

2021 Volume 8 Number 4 (June)

http://doi.org/10.9770/jesi.2021.8.4(28)

Regional Innovation on Smart Specialisation Strategies (RIS3). The Smart Specialisation approach is one of the key pillars of the Europe 2020 Strategy in terms of economic development and growth policy thinking (McCann \& Ortega-Argilés, 2011) as well as an approach to avoid dissipation of European Union (EU) funds among regions (Rusu, 2013). The basic idea can be traced back to the rising productivity gap between Europe and the USA in mid 90's, when European policy makers had to look for alternative policies to impede further economic back path. After announcing the Smart Specialisation initiative on European level, all NUTS-2 regions were in a position to develop individual strategies according to this top-down policy and include sufficient monitoring systems. With the ending of the funding period 2014-2020, the strategies will be monitored on successful policy implementation deriving recommendations to amend the regional Smart Specialisation Strategies for the upcoming funding period 20212027.

To continue sustainable development in Europe, the European Green Deal was announced as the new Growth Strategy for the EU towards a more sustainable economic and society (EC, 2019). This strategy aims to cover all economic sectors by introducing new growth opportunities and activities. However, new strategic governance capacities are required for successful implementation (Larosse et. al., 2020). The Smart Specialisation approach follows the same idea to identify and use regional potentials to support innovative and competitive development. Therefore, Smart Specialisation policy can be a key pillar in the European governance transformation to reach the objectives of the European Green Deal until 2050. Thus, a specialisation by the regions using Key Enabling Technologies (KETs) or Knowledge Intensive Business Services (KIBs) to particular fields or priorities is unavoidable.

The strategic matrix on SBSR Marketing and Branding by means of Collective Learning and Entrepreneurial Discovery on individual SME level as shown in Table 3 below proposes key fundamental actions that are necessary across the entire Regional Ecosystem Interaction Domains to enable blue SMEs to build up innovation capacity starting from:

a) resources pooling and generation;

b) over deployment of resources for innovation;

c) towards improving strategic positioning and competitiveness through rare, non-imitable, and nonsubstitutable as well as valuable resources, competencies and capacities; and

d) arriving at holistic perception of an organisation and the entire region as a sustainable and smart one.

These four fundamental steps empower regional SMEs to develop their own strategies and / or improve existing ones in a step-by-step approach addressing challenges, needs and expectations from the entire social and economic system. Considering given European policies for business strategy development, SMEs shall parse that innovation in the EU, and especially in the SBSR, which due to its natural position is bound to environmental compliance, as a policy-driven approach, where most of business interactions under the given new transformative conditions, such as high resource efficiency and sustainability, environmental compliance, social inclusion and growing integration, require new (re)combination of strategic actions and adaptations. Only by doing this, the SBSR and its main business players will be able to break through the peripheral position the region has occupied and to excel itself as the region with strong knowledge, sound learning \& discovery potentials and placement of customers and users into the centre, thus leading towards shared value creation, which, in turn, is at the heart of the brand.

The Table below merges the four introduced Interaction Domains of blue SMEs (columns) and four key areas to be considered for participation in the RIS3 from a business perspective. As argued in the earlier sub-chapter considering European policies for business strategy development creates direct and indirect benefits for SMEs. The same idea applies for Smart Specialisation and the regionally identified priorities. From the business perspective the Entrepreneurial Discovery Process (EDP) is a crucial component to implement this innovation policy. Such processes are based on Open Innovation as well as interdisciplinary and collaborative approaches. Nevertheless, 
detailed "planning" of an EDP is not possible, but can be fostered and accelerated through business activities and strategies.

Table 3. SBSR Marketing and Branding through Learning and Discovery

\begin{tabular}{|c|c|c|c|c|}
\hline & Technology Architecture & Institutional Architecture & $\begin{array}{c}\text { Socio- Environment } \\
\text { Architecture }\end{array}$ & $\begin{array}{c}\text { Market (Place-based) } \\
\text { Architecture }\end{array}$ \\
\hline $\begin{array}{l}\text { Resources \& } \\
\text { Competence } \\
\text { Portfolio }\end{array}$ & 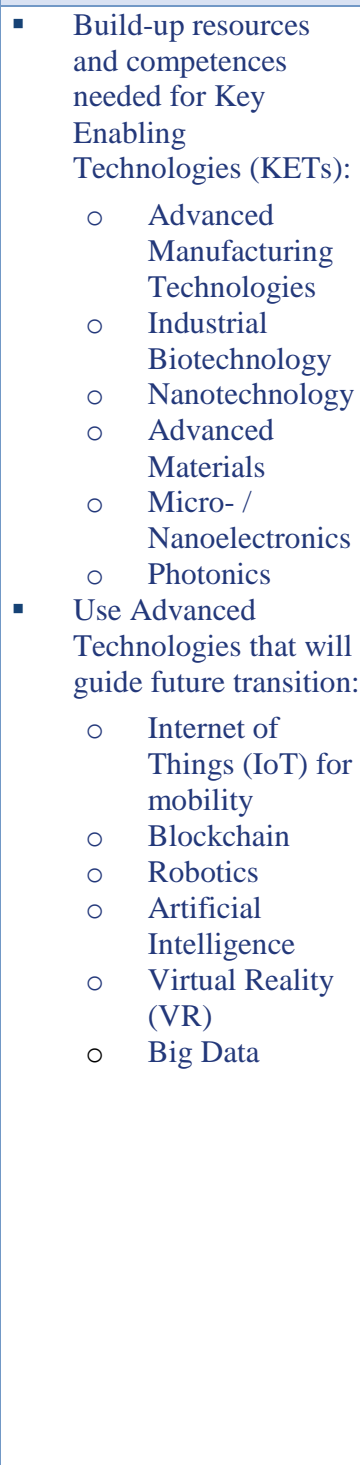 & $\begin{array}{l}\text { - Align your next years' } \\
\text { strategy, business plans } \\
\text { and business modelling in } \\
\text { line with the key EU } \\
\text { priorities on structural and } \\
\text { regional levels: } \\
\text { o political priorities } \\
\text { of the EC for 2019- } \\
\text { 2024: protecting } \\
\text { citizens and } \\
\text { freedoms; } \\
\text { developing a strong } \\
\text { and vibrant } \\
\text { economic base; } \\
\text { building a climate- } \\
\text { neutral, green, fair } \\
\text { and social Europe; } \\
\text { promoting European } \\
\text { interests and values } \\
\text { on the global stage } \\
\text { Align your activities } \\
\text { on regional level } \\
\text { with the EU regional } \\
\text { development and } \\
\text { cohesion policy: } \\
\text { smart Europe, } \\
\text { greener and carbon } \\
\text { free Europe, } \\
\text { connected Europe, } \\
\text { social Europe and } \\
\text { Europe closer to } \\
\text { citizens } \\
\text { Consider the European } \\
\text { Green Deal priorities and } \\
\text { targets for } 2030 \text { and } 2050 \\
\text { Ensure your business } \\
\text { performance and future } \\
\text { actions in line with the UN } \\
\text { Sustainable Development } \\
\text { Goals (SDGs) }\end{array}$ & $\begin{array}{l}\text { - Focus on intertwined } \\
\text { domains of social } \\
\text { interactions: } \\
\text { o } \quad \text { Human Capital } \\
\text { o Cultural } \\
\quad \text { Capital } \\
\quad \text { Regional } \\
\quad \text { Identity) } \\
\text { Knowledge } \\
\quad \text { Capital } \\
\text { Strengthen } \\
\text { interpersonal } \\
\text { communication skills } \\
\text { in and outside your } \\
\text { business } \\
\text { Focus on } \\
\text { multicultural } \\
\text { competence building } \\
\text { Strengthen } \\
\text { multilingual } \\
\text { competence base } \\
\text { Improve your } \\
\text { emotional } \\
\text { intelligence: } \\
\text { empathy, leadership, } \\
\text { shared responsibility, } \\
\text { cooperation, stress } \\
\text { tolerance } \\
\text { Be open for new } \\
\text { things and engage } \\
\text { into learning avenues }\end{array}$ & $\begin{array}{l}\text { Know cost structure } \\
\text { of your own and } \\
\text { your competitors' } \\
\text { offers on the market } \\
\text { Consider existing } \\
\text { and projected market } \\
\text { share of offerings } \\
\text { Strengthen } \\
\text { positioning on the } \\
\text { market through } \\
\text { entire ecosystem } \\
\text { integration } \\
\text { Accept customer / } \\
\text { user integration into } \\
\text { new offering } \\
\text { development } \\
\text { Comply with } \\
\text { sustainability } \\
\text { principles enabling } \\
\text { social equity, } \\
\text { environmental } \\
\text { responsibility and } \\
\text { economic efficiency } \\
\text { Focus on } \\
\text { Knowledge-Intensive } \\
\text { Business Services } \\
\text { (KIBS) in your } \\
\text { offering portfolio }\end{array}$ \\
\hline $\begin{array}{l}\text { Innovation } \\
\text { (Processes) } \\
\text { \& Strategic } \\
\text { Positioning }\end{array}$ & $\begin{array}{l}\text { Consider } \\
\text { diversification of your } \\
\text { offering portfolio by } \\
\text { moving rather from } \\
\text { sole product offering } \\
\text { towards product-as-a- } \\
\text { service offerings, thus }\end{array}$ & $\begin{array}{l}\text { Make your offerings: } \\
\text { products, services } \\
\text { processes or marketing } \\
\text { solutions compliant with } \\
\text { EU policies and } \\
\text { governance }\end{array}$ & $\begin{array}{l}\text { Mind sustainability } \\
\text { principals once } \\
\text { offering something to } \\
\text { the market } \\
\text { - Ensure that any of } \\
\text { your offerings is in } \\
\text { line with the }\end{array}$ & $\begin{array}{ll}\text { - } & \text { Engage into } \\
\text { Entrepreneurial } \\
\text { Discovery Processes } \\
\text { - Apply for available } \\
\text { Research \& } \\
\text { Development Funds }\end{array}$ \\
\hline
\end{tabular}




\begin{tabular}{|c|c|c|c|c|}
\hline & Technology Architecture & Institutional Architecture & $\begin{array}{c}\text { Socio- Environment } \\
\text { Architecture }\end{array}$ & $\begin{array}{l}\text { Market (Place-based) } \\
\text { Architecture }\end{array}$ \\
\hline & $\begin{array}{l}\text { enabling entering of } \\
\text { niche markets } \\
\text { Develop your } \\
\text { innovative offerings } \\
\text { using processual and } \\
\text { holistic innovation } \\
\text { canvas } \\
\text { Engage more in } \\
\text { tangible piloting and } \\
\text { demonstration actions }\end{array}$ & $\begin{array}{l}\text { Utilise innovation driving } \\
\text { EU tools and incentives or } \\
\text { your business acceleration } \\
\text { Strengthen your marketing } \\
\text { \& positioning through } \\
\text { customer / user } \\
\text { engagement and more } \\
\text { interactions } \\
\text { Develop supportive } \\
\text { business models }\end{array}$ & $\begin{array}{l}\text { environmental policy } \\
\text { and regulations } \\
\text { - Focus on natural } \\
\text { resources reduction } \\
\text { for your trade } \\
\text { offerings } \\
\text { - Think of waste as a } \\
\text { resource }\end{array}$ & $\begin{array}{l}\text { on local, national and } \\
\text { EU level } \\
\text { Utilise Growth } \\
\text { Strategies for your } \\
\text { own business } \\
\text { purposes }\end{array}$ \\
\hline $\begin{array}{l}\text { Branding \& } \\
\text { Brand } \\
\text { Positioning }\end{array}$ & $\begin{array}{l}\text { Become a lighthouse } \\
\text { in Digital } \\
\text { Transformation in } \\
\text { Blue Economy } \\
\text { - } \quad \begin{array}{l}\text { Differentiate yourself } \\
\text { as first-mover }\end{array}\end{array}$ & $\begin{array}{l}\text { Engage into Smart } \\
\text { Specialisation with areas } \\
\text { of energy, biodiversity, } \\
\text { circular economy, } \\
\text { maritime tourism, } \\
\text { aquaculture and thus } \\
\text { ensure public governance } \\
\text { support for your business }\end{array}$ & $\begin{array}{l}\text { Position yourself as } \\
\text { agents in Social and } \\
\text { Environmental } \\
\text { Compliance } \\
\text { - Use credentials of } \\
\text { Circular Economy } \\
\text { and promote yourself } \\
\text { as care-taker }\end{array}$ & $\begin{array}{l}\text { Consider different } \\
\text { marketing activities } \\
\text { for different markets } \\
\text { you are operating in } \\
\text { - Uphold sustainable } \\
\text { transformation } \\
\text { through new learning } \\
\text { cycles }\end{array}$ \\
\hline $\begin{array}{l}\text { Sustainable } \\
\text { Competitive } \\
\text { Organisation } \\
\text { \& Ecosystem }\end{array}$ & $\begin{array}{l}\text { Improve and boost } \\
\text { your operational and } \\
\text { technological capacity } \\
\text { - Established } \\
\text { infrastructure that will } \\
\text { meet future production } \\
\text { or servitisation } \\
\text { requirements }\end{array}$ & $\begin{array}{l}\text { Build up your future } \\
\text { business around pillars of } \\
\text { resource efficiency, } \\
\text { differentiation and } \\
\text { strategic Flexibility } \\
\text { Capitalise on build up trust } \\
\text { and customer satisfaction, } \\
\text { thus enabling sustainable } \\
\text { growth through customer / } \\
\text { user bonding }\end{array}$ & $\begin{array}{l}\text { Benefit from state- } \\
\text { of-the-art knowledge } \\
\text { and competences } \\
\text { Build up competitive } \\
\text { and dynamic } \\
\text { capabilities } \\
\text { Benefit from social } \\
\text { mindset, thus } \\
\text { increasing your } \\
\text { visibility and } \\
\text { reliability in public } \\
\text { and non-profit } \\
\text { sectors }\end{array}$ & $\begin{array}{ll}\text { Become strong } \\
\text { partner in sustainable } \\
\text { supply chains }\end{array}$ \\
\hline
\end{tabular}

Source. Compiled by authors.

Within the table, key facts and areas are listed to classify the four introduced interaction domains to the Smart Specialisation concept. In addition, branding is included as main objective of this conducted strategy. Again, this table aims at revealing key points that should be reflected in business strategies for future business development in line with RIS3 and of course Blue Economy.

\subsection{Marketing and Branding SBSR with A Shared Vision for the Future}

The last strategic matrix of layer delivers key strategic actions placed in the time axis. In this, specific short- and long-term actions are proposed that enable regional SMEs and the entire region to smoothly move towards digital transformation, smart specialisation and thus strengthen competitive position and branding of the region and SMEs innovation outputs. The previous two sub-chapters already mentioned two important innovation policies for future European and SBSR development. Hence, from the SMEs perspective not all activities may fit into this kind of policies. Nevertheless, the uncertainty of failing will strongly decrease for all businesses being able to adapt future visions for the own strategy development in line with mentioned policies. Therefore, the following Table 4 provides specific actions, which should be part of any companies' strategy and future orientation of the own business under 
the three identified future visions of Digital Transformation, Smart Specialisation and Branding. Activities are divided into short-term and long-term perspective and are shortly justified from the present point of view.

Table 4. SBSR Marketing and Branding through Shared Vision and Value Creation

\begin{tabular}{|c|c|c|c|c|c|}
\hline \multirow[t]{2}{*}{ Future Vision } & \multicolumn{3}{|c|}{ Short-Term (2025) } & \multicolumn{2}{|c|}{ Long-Term (2030 - 2035) } \\
\hline & Why & & What & Why & What \\
\hline $\begin{array}{c}\text { Digital } \\
\text { Transformation }\end{array}$ & $\begin{array}{l}\text { - COVID-19 } \\
\text { pandemic hit global, } \\
\text { national and } \\
\text { regional economies, } \\
\text { in particular remote } \\
\text { peripheral regions } \\
\text { like SBSR is } \\
\text { - Modern business } \\
\text { requires shared } \\
\text { value creation } \\
\text { through increased } \\
\text { customer / user } \\
\text { engagement } \\
\text { Increase } \\
\text { competitiveness } \\
\text { Design efficient } \\
\text { enterprise processes }\end{array}$ & $\begin{array}{l}\rightarrow \\
\Rightarrow \\
\Rightarrow\end{array}$ & $\begin{array}{l}\text { Implement continuous } \\
\text { and tailored made } \\
\text { competence building in } \\
\text { future industry, } \\
\text { technology and } \\
\text { demanded skills areas } \\
\text { Upgrade your digital } \\
\text { infrastructure in due } \\
\text { course } \\
\text { Automate your } \\
\text { physical infrastructure } \\
\text { Engage into networks } \\
\text { and clusters enabling } \\
\text { to overcome isolation }\end{array}$ & 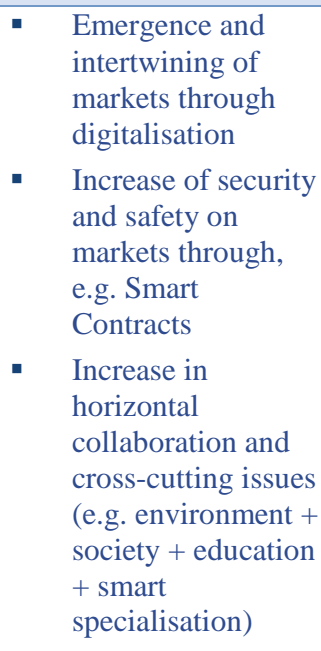 &  \\
\hline $\begin{array}{c}\text { Smart } \\
\text { Specialisation }\end{array}$ & $\begin{array}{l}\text { - Access to funds on } \\
\text { regional level will } \\
\text { be bound to } \\
\text { compliance to Eu } \\
\text { cohesion policy and } \\
\text { regional } \\
\text { development } \\
\text { policies } \\
\text { Competition over } \\
\text { EU funds for } \\
\text { innovation will } \\
\text { increase } \\
\text { EU will guide future } \\
\text { industry } \\
\text { development } \\
\text { through } \\
\text { prioritisation of } \\
\text { specific highly } \\
\text { competitive sectors } \\
\text { and areas }\end{array}$ & $\begin{array}{l}\Rightarrow \\
\Rightarrow \\
\Rightarrow \\
\Rightarrow\end{array}$ & $\begin{array}{l}\text { Check if your business } \\
\text { plans are in line with } \\
\text { regional, national or } \\
\text { EU priorities } \\
\text { Check market structure } \\
\text { and market conditions } \\
\text { in markets in which } \\
\text { you operate } \\
\text { Foster inter- and intra- } \\
\text { Entrepreneurial } \\
\text { Discovery Processes } \\
\text { Ensure your innovation } \\
\text { security through patent } \\
\text { applications } \\
\text { Focus on cross-sectoral } \\
\text { collaboration } \\
\text { Concentrate on } \\
\text { Emerging Industries }\end{array}$ & $\begin{array}{l}\text { Transition to } \\
\text { uncertain future } \\
\text { markets with } \\
\text { volatile, complex } \\
\text { and ambiguous } \\
\text { environment } \\
\text { Increase of Future } \\
\text { and Emerging } \\
\text { Technologies } \\
\text { through dedicated } \\
\text { funding (e.g. } \\
\text { Horizon Europe } \\
\text { Programme) } \\
\text { Increased global } \\
\text { competition with } \\
\text { new emerging } \\
\text { world regions } \\
\text { Regional resource } \\
\text { vulnerability }\end{array}$ &  \\
\hline $\begin{array}{c}\text { Branding \& } \\
\text { Competitive } \\
\text { Edge }\end{array}$ & $\begin{array}{ll}\text { - } & \text { Synergy and scale } \\
\text { effects } \\
\text { - } & \text { Increase in } \\
\text { intersectoral } \\
\text { cooperation }\end{array}$ & & $\begin{array}{l}\text { Enter specialised } \\
\text { InterMarE South Baltic } \\
\text { network and brand } \\
\text { your business together } \\
\text { with other - acting }\end{array}$ & 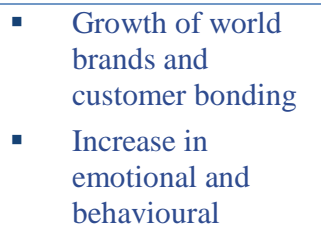 & 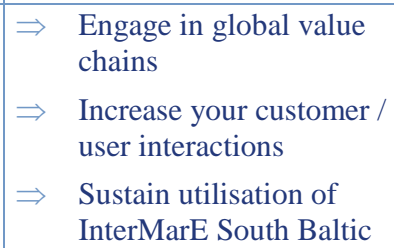 \\
\hline
\end{tabular}


ENTREPRENEURSHIP AND SUSTAINABILITY ISSUES

ISSN 2345-0282 (online) http://jssidoi.org/jesi/

2021 Volume 8 Number 4 (June)

http://doi.org/10.9770/jesi.2021.8.4(28)

\begin{tabular}{|c|c|c|c|c|}
\hline \multirow[t]{2}{*}{ Future Vision } & \multicolumn{2}{|c|}{ Short-Term (2025) } & \multicolumn{2}{|c|}{ Long-Term (2030 - 2035) } \\
\hline & Why & What & Why & What \\
\hline & 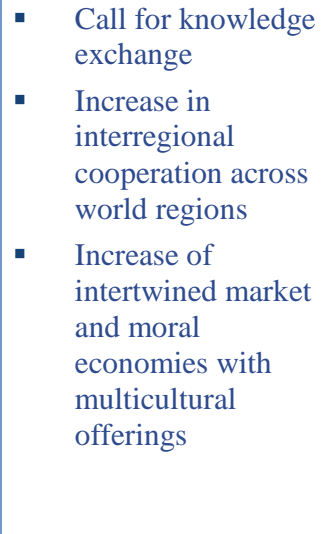 & 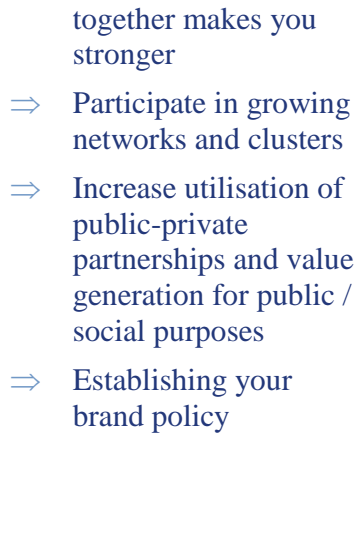 & $\begin{array}{l}\text { marketing through } \\
\text { more visualised and } \\
\text { emotional appealing } \\
\text { Increase in } \\
\text { competition about } \\
\text { customer / user data } \\
\text { Increase focus on } \\
\text { servitisation rather } \\
\text { on pure product } \\
\text { offering on the } \\
\text { market, thus } \\
\text { making customer / } \\
\text { user a central } \\
\text { offering element }\end{array}$ & 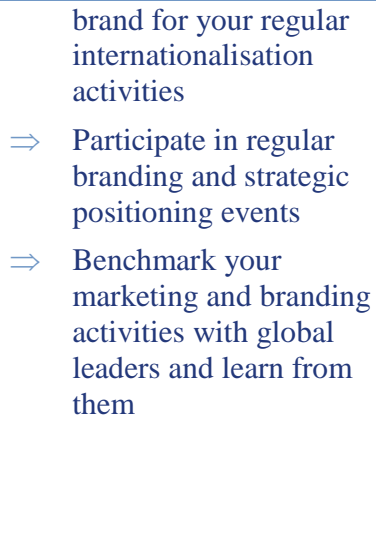 \\
\hline
\end{tabular}

Source. Compiled by authors.

Future Visions are a selection of currently discussed obstacles for blue companies in the SBSR and could be enlarged on individual basis with further visions such as Green Technologies or Sustainable / Regional Supply Chains. Nevertheless, following previous argumentation and the character of this Marketing and Branding Strategy on macro-level, the three proposed future visions should be identified by every SME of the SBSR and therefore add value to this strategy document. The proposed actions need to be adapted and further developed into clear actions by each company depending on the individual needs and obstacles, which means to transform this theoretical strategy into practical actions in daily business of the respective SME. However, the Table below offers a first approach as a framework to develop individual growth and marketing strategies within the companies by presenting key issues to be analysed and elaborated for the short- and long-term perspective of blue SMEs in the SBSR.

\section{Discussion and Conclusions}

SBSR Marketing and Branding Strategy builds upon three blocks and shall be perceived from an ecosystem and processual perspectives. In this, SBSR Marketing and Branding is driven by the following strategic actions:

a) establishing tools for resource pooling, allocation and (re)combination leading to knowledge excellence and, in turn, innovation development, arriving at sustainable organisational (regional) ecosystem;

b) providing key entrepreneurial and creative discovery related tools; and

c) transforming the SBSR into a Brand with shared future vision and joint strategic positioning.

The authors of the Marketing and Branding Strategy believe that in order to be competitive on the market (would it be domestically, regionally or macro-regionally), it is essential to adopt innovation-driven transformation concept and to perceive SBSR Marketing \& Branding as an on-going continuous and holistic process. Therefore, the following conclusions and managerial implications are formulated:

- Innovation approach and its processual meaning embraces the idea of marketing and branding, as from the processual perspective innovation results from a thorough customer and user-engagement (who, where and how), step-by-step approaches (processual perspective) and sound perception of a product / service, 


\section{ENTREPRENEURSHIP AND SUSTAINABILITY ISSUES}

ISSN 2345-0282 (online) http://jssidoi.org/jesi/

2021 Volume 8 Number 4 (June)

http://doi.org/10.9770/jesi.2021.8.4(28)

organisational process or marketing model (depending on the innovation goal itself) delivering shared monetary and social value for both customers / users and owners (innovators).

- In this, in its nature, innovation concept already includes key elements of the 7 Ps concept (7 elements starting with "P"), i.e. Product, Place, Price, Promotion, People, Processes and Physical Evidence (tangible and intangible features of the innovation, like. shape, design, experience, usability, etc.).

- As a result, with this approach, beneficiaries of this Marketing and Branding Strategy do not need explicitly to focus on $7 \mathrm{Ps}$, as during the process of innovation, all these 7 aspects are consciously covered, which showcases practical innovation development step and how you as beneficiaries can combine and dovetail all these issues into one approach - innovation process.

- Further, advocating innovation-driven approach yields further benefits: innovation approach enables to generate changes in an organisation from an ecosystem and holistic perspective, i.e. inside-out (building up innovation competencies and capacities) and outside-in (improving external performance, competitive edge of an organisation through better tailored-made marketing and branding activities). This paves the wave for both development of new managerial competencies (organisational level) to meet transformation needs in the next future on the one hand, and smoothens the shift in the paradigm, e.g. system changes on the market, e.g. new technologies emergence (external market level) on the other hand.

- Innovation approach is proved to be a key to growth, competitiveness and differentiation. As a result, combination of marketing and branding activities for the SBSR and the creation of "InterMarE South Baltic" Brand is a first essential step for the region and regional players to set themselves from other counterparts.

Theoretically, this research contributes towards behavioural and organisation studies and, in particular, enhanced regional marketing and branding scientific contributions. The most important scientific benefit remains a first contribution towards marketing and branding discourse in the SBSR that go beyond touristic and regional identity considerations, but rather addresses challenges and raises potentials immanent with regional businesses that mainly are responsible for economic growth. In addition, the paper contributes to the growing needs to include social aspects ans strengthen Blue Growth discourses from social sciences' perspective. The research purports that succeeding research contributions are essential on tracing effects of marketing and branding within SMEs and other stakeholders that apply this strategy and principle steps. The same applies to quantification of strategy transferability and applicability outside the region. In addition, underlying interactions among involved stakeholders and importance of multi-level governance for Blue Economy growth, in particular, support from helix actors for regional blue SMEs in their growth strategies' formulation and implementation should be put as key research topics both on academic and policy agendas.

\section{References}

Alberti, F. G., Giusti, J. D., \& Pizzurno, E. (2016). The role of institutions for collaboration in setting a competitive cluster ecosystem: the case of the French omega-3 cluster. International journal of competitiveness, 1(1), 4-32.

Afriyie, S., Du, J., \& Musah, A. A. I. (2019). Innovation and marketing performance of SME in an emerging economy: the moderating effect of transformational leadership. Journal of Global Entrepreneurship Research, 9(1), 1-25.

Ahlgren, J. (2019). Circular Baltic 2030. Circular economy in the Baltic Sea Region and Beyond.

Andersson, M. (2007). Region branding: The case of the Baltic Sea region. Place Branding and Public Diplomacy, 3(2), $120-130$.

Andersson, I. (2014). Placing place branding: an analysis of an emerging research field in human geography. Geografisk Tidsskrift-Danish Journal of Geography, 114(2), 143-155.

Andersson, I. (2016). Green cities' going greener? Local environmental policy-making and place branding in the 'Greenest City in Europe. European planning studies, 24(6), 1197-1215. 


\section{ENTREPRENEURSHIP AND SUSTAINABILITY ISSUES}

ISSN 2345-0282 (online) http://jssidoi.org/jesi/

2021 Volume 8 Number 4 (June)

http://doi.org/10.9770/jesi.2021.8.4(28)

Arbnor, I., \& Bjerke, B. (2008). Methodology for creating business knowledge. Sage.

Arbo, P., Knol, M., Linke, S., \& Martin, K. S. (2018). The transformation of the oceans and the future of marine social science. Maritime Studies, 17(3), 295-304.

Beyersdorff, S., \& Lanthen, E. (2018). Baltic 2030: Bumps on the Road. How the Baltic Sea States are performing on the SDGs. Nordic Council of Ministers and Council of the Baltic Sea States.

Böhme, K., Zillmer, S., Hans, S., Antikainen, J., \& Pyykkonen, S. (2016). Looking towards 2030: Preparing the Baltic Sea Region for the Future. Full Report.

Borges, L. A., \& Topsiduo, M. (2020). The territorial future of the Baltic Sea Region. Insights for policy makers. ESPON BT2040 Seminar. ESPON.

Costa, P. T., \& Veríssimo, M. (2020). The Sea by Tradition: From the Slogan to the Brand-Exploring a Successful Case of Territorial Strategy Anchored in the Sea and Tourism. In Managing, Marketing, and Maintaining Maritime and Coastal Tourism (pp. 264-283). IGI Global.

Creswell, J. W. (2013). Research design: Qualitative, quantitative, and mixed methods approaches. Sage publications.

Ertör, I., \& Hadjimichael, M. (2020). Blue degrowth and the politics of the sea: rethinking the blue economy. Sustainability Science, 15(1), $1-10$.

European Commission (2012). COMMUNICATION FROM THE COMMISSION TO THE EUROPEAN PARLIAMENT, THE COUNCIL, THE EUROPEAN ECONOMIC AND SOCIAL COMMITTEE AND THE COMMITTEE OF THE REGIONS Blue Growth opportunities for marine and maritime sustainable growth, COM/2012/0494 final, https://eurlex.europa.eu/legalcontent/EN/ALL/?uri=CELEX\%3A52012DC0494 accessed on 30th October 2020.

European Commission (2013a) Regional policy for smart growth of SMEs: Guide for Managing Authorities and bodies in charge of the development and implementation of Research and Innovation Strategies for Smart Specialisation,

http://ec.europa.eu/regional policy/sources/docgener/studies/pdf/sme guide/sme guide en.pdf accessed 15th September 2020.

European Commission (2013b). Entrepreneurship 2020 Action Plan: Reigniting the entrepreneurial spirit in Europe,

https://eurlex.europa.eu/LexUriServ/LexUriServ.do?uri=COM:2012:0795:FIN:EN:PDF, accessed 15th September 2020.

European Commission (2017). Commission Staff Working Document: Report on the Blue Growth Strategy Towards More Sustainable Growth and Jobs in the Blue Economy. SWD (2017) 128 final, https://ec.europa.eu/maritimeaffairs/sites/maritimeaffairs/files/swd2017128_en.pdf, accessed on 30th October 2020.

European Commission (2018). The 2018 annual economic report on the EU blue economy. European Commission.

European Commission (2019a), The European Green Deal, Communication from the Commission, December 11, 2019, from https://eurlex.europa.eu/legal-content/EN/TXT/?qid=1588580774040\&uri=CELEX:52019DC0640

European Commission (2019c). Annual Report on European SMEs 2018/2019. Research \& Development and Innovation by SMEs. SME Performance Review 2018/2019. PwC Luxembourg.

European Commission (2020b). European Panorama of Clusters and Industrial Change. Performance of Strong Clusters across 51 Sectors and the Role of Firm Size in Driving Specialisation. European Union, Luxembourg.

European Commission (2021). EU Strategy for the Baltic Sea Region. Action Plan (Com(2009) 248 final.

Finoti, L., Didonet, S. R., Toaldo, A. M., \& Martins, T. S. (2017). The role of the marketing strategy process in the innovativenessperformance relationship of SMEs. Marketing Intelligence \& Planning. Marketing Intelligence \& Planning, 35(3), 298-315. https://doi.org/10.1108/MIP-01-2016-0005

Hącia, E., \& Łapko, A. (2017, October). Territorial cooperation for the development of nautical tourism in the Southern Baltic Rim. In DIEM: Dubrovnik International Economic Meeting, 3(1), 780-792. Sveučilište u Dubrovniku.

Hess, J. (2011), Die Identität des Ostseeraums. Greifswalder Beiträge zur Regional-, Freizeit- und Tourismusforschung (The identity of the Baltic Sea region. Greifswald contributions to regional, leisure and tourism research), 21, 76-91. 


\section{ENTREPRENEURSHIP AND SUSTAINABILITY ISSUES}

ISSN 2345-0282 (online) http://jssidoi.org/jesi/

2021 Volume 8 Number 4 (June)

http://doi.org/10.9770/jesi.2021.8.4(28)

Gerlitz, L., Philipp, R., \& Beifert, A. (2017). Smart and Sustainable Cross-Sectoral Stakeholder Integration into Macro-Regional LNG Value Chain. In International Conference on Reliability and Statistics in Transportation and Communication (pp. 112-126). Springer, Cham.

Gerlitz, L., Meyer, C., \& Prause, G. (2020). Methodology approach on benchmarking Regional Innovation on Smart Specialisation (RIS3): a joint macro-regional tool to regional performance evaluation and monitoring in Central Europe. Entrepreneurship and Sustainability Issues, $8(2), 1359$.

Hack, A., Prause, G., Maknyte, L. (2012). Design Management and Branding for SMEs: Experiences from the DesignSHIP Project. In: Muravska, T.; Prause, G. (Ed.). European Integration and Baltic Sea Region Studies, (131-150). Berliner Wissenschafts-Verlag.

Jean, R. J. B., Sinkovics, R. R., \& Kim, D. (2010). Drivers and performance outcomes of relationship learning for suppliers in cross-border customer-supplier relationships: The role of communication culture. Journal of International Marketing, 18(1), 63-85.

Johnston, R. J., Gregory, D., Pratt, G. and Watts, M. (eds.). (2000). Regions and Regional Geography. In: The Dictionary of Human Geography, Blackwell Publishing, pp. 687-689.

Ketels, C., \& Pedersen, H. J. (2016). State of the region report; The Top of Europe-Doing Well Today, Feeling Worried about Tomorrow. Baltic Development Forum.

Ketels, C., Pedersen, H. J., \& Olsson, M. (2017). State of the Region Report 2017: The Top of Europe-A Competitive Baltic Sea Region Ready for the Future? Baltic Development Forum.

Knippschild, R. (2011). Cross-border spatial planning: Understanding, designing and managing cooperation processes in the German-PolishCzech borderland. European Planning Studies, 19(4), 629-645.

Łapko, A., \& Müller, M. (2018). Destination Branding Process Exampled by the South Coast Baltic Region. International Journal of Contemporary Management, 17(4), 281-299.

Larosse, J., Corpakis, D. \& Tuffs, R. (2020). The Green Deal and Smart Specialisation, Version 4, February 2020.

Lee, S. H., Shenkar, O., \& Li, J. (2008). Cultural distance, investment flow, and control in cross-border cooperation. Strategic Management Journal, 29(10), 1117-1125.

Lincoln, Y. S., Lynham, S. A., \& Guba, E. G. (2011). Paradigmatic controversies, contradictions, and emerging confluences revisited. In: N. K. Denzin \& Y. S. Lincoln (Eds.). The SAGE Handbook of Qualitative Research, 4th Edition, Thousand Oaks, CA: Sage, pp. 97-128.

Manniche, J., Topsø Larsen, K., Brandt Broegaard, R., \& Holland, E. (2017). Destination: A circular tourism economy: A handbook for transitioning toward a circular economy within the tourism and hospitality sectors in the South Baltic Region. https://circulareconomy.europa.eu/platform/sites/default/files/cirtoinno-handbook_eng-rev.-4.pdf

McCann, P. \& Ortega-Argilés, R. (2011). Smart Specialisation, Regional Growth and Applications to EU Cohesion Policy. Economic Geography Working Paper 2011: Faculty of Spatial Sciences, University of Groningen.

Merriam, S. B. (1998). Qualitative Research and Case Study Applications in Education. Revised and Expanded from" Case Study Research in Education.". Jossey-Bass Publishers, 350 Sansome St, San Francisco, CA 94104.

Metzger, J., \& Schmitt, P. (2012). When soft spaces harden: the EU strategy for the Baltic Sea Region. Environment and Planning A, 44(2), 263-280.

Nilsson, J. H., Eskilsson, L., \& Ek, R. (2010). Creating Cross-Border destinations: Interreg programmes and regionalisation in the Baltic sea area. Scandinavian Journal of Hospitality and Tourism, 10(2), 153-172.

OECD (2019). Measuring Distance to the SDG Targets 2019: An Assessment of Where OECD Countries Stand, PECD Publishing, Paris.

Olsson, V. (2015). Local and regional food-perspectives from the south Baltic region of Sweden. perspectives on local and regional food in the South Baltic Region, 43. 


\section{ENTREPRENEURSHIP AND SUSTAINABILITY ISSUES}

ISSN 2345-0282 (online) http://jssidoi.org/jesi/

2021 Volume 8 Number 4 (June)

http://doi.org/10.9770/jesi.2021.8.4(28)

Paasi, A. (2001). Europe as a social process and discourse: considerations of place, boundaries and identity. European urban and regional studies, 8(1), 7-28.

Paasi, A. (2009). Regions and Regional Dynamics. In. C. Rumford (ed.), The SAGE Handbook of European Studies, SAGE Publications LTD London, 465-484.

Pasquinelli, C. (2013). Competition, cooperation and co-opetition: Unfolding the process of inter-territorial branding. Urban Research \& Practice, 6(1), 1-18.

Petrenko, A., Brinkman, P., \& Olsson, V. (2014). Putting Local Food on the Table: Enhancing Competitiveness of Producers of Local and Regional Food in the South Baltic Region. http://www.eskoler.dk/regfood.eu/wp-content/uploads/2013/07/REGFOOD-concept-paper1.pdf

Philipp, R., Prause, G., \& Meyer, C. (2020). Blue growth potential in south Baltic sea region. Transport and Telecommunication, 21(1), 6983.

Prause, G., Gerlitz, L., \& Hoffmann, T. (2018). Design protection in managing sustainable user- driven innovation in SMEs. Journal of Japanese Management, 3(1).

Routes 4U (2017). Branding Strategy for the Baltic Sea Region. Analysis and Recommendations.

Rusu, M. (2013). Smart Specialisation a Possible Solution to the New Global Challenges, Procedia Economics and Finance, 6, 128 - 136. https://doi.org/10.1016/S2212-5671(13)00124-X

Skarmeas, D., Zeriti, A., \& Baltas, G. (2016). Relationship value: Drivers and outcomes in international marketing channels. Journal of international marketing, 24(1), 22-40.

Stiller, S., \& Wedemeier, J. (2011). Zukunft Ostseeraum: Potenziale und Herausforderungen (No. 16). HWWI Policy Report.

Swacha, J., Marx, S., Muszyńska, K., Niedoszytko, G., Podlesińska, W., \& Eglinskiene, J. (2018). Cross-border collaboration for innovation in tourism: The case of oceanographic museums. European Journal of Service Management, 27, 425-432.

Tägil, S. 1983. The Question of Border Regions in Western Europe: An Historical Background. In: M. Anderson (ed.), Frontier Regions in Western Europe, Frank Cass London, pp.18-34.

Treder, H., \& Kulawczuk, P. (2012). Export marketing of small and medium-sized enterprises in the South Baltic Region, https://www.researchgate.net/profile/Anna_Nikodemska-Wolowik/publication/325763059_Establishing_a_long_term_corporate_identity_on_the_foreign_market/links/5b23ffd3a6fdcc697466797d/Establishing-a-long-term-corporate-identity-on-the foreign-market.pdf accessed 1st October 2020.

Vìtola, A. (2015). Innovation policy mix in a multi-level context: The case of the Baltic Sea Region countries. Science and Public Policy, $42(3), 401-414$

Yin, R. K. (2018). Case study research and applications. Sage.

\section{Acknowledgements}

This research was supported by the Interreg project "InterMarE" project that was implemented in the frame of the Interreg South Baltic Programme 2014-2020 from July 2017 to Jun 2021. The project is based on the research and practical gaps highlighting the needs to support maritime SMEs in economic development by increasing their visibility under one joint regional brand. 

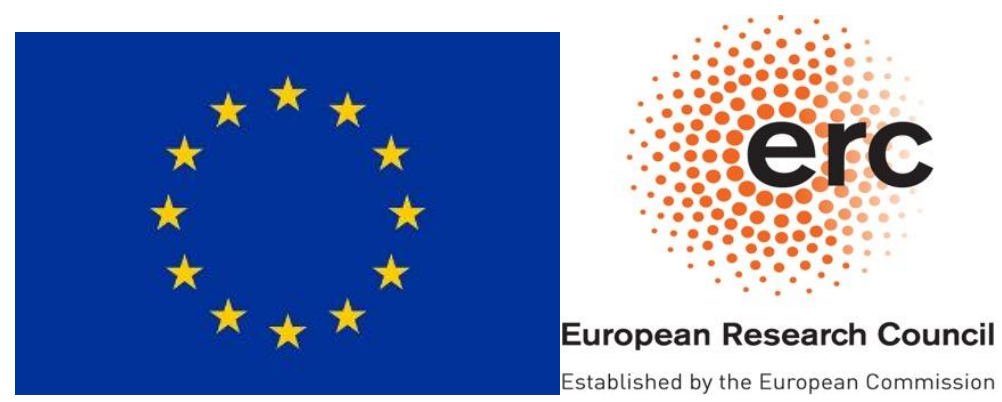

Laima GERLITZ, PhD. Laima Gerlitz is a researcher at Wismar University of Applied Sciences: Technology, Business and Design and PhD Student at Tallinn University of Technology within the fields of project, design and transport related management. Since 2014, Laima Gerlitz is researching on her PhD topic "Design as Success Factor for Innovation, Competitiveness and Smart Growth". Key fields of research are design and innovation, strategic design management, design management for enterprises, competitiveness and value creation deriving from design-driven approaches in organisational settings, particularly in the context of small manufacturing and high-tech enterprises and start-ups.

ORCID ID: orcid.org/0000-0002-7127-7678

Christopher MEYER, M.Sc. Christopher Meyer coordinates several European research projects at the European Project Center associated to the University of Wismar. After his master degree in public economics, he started his studies as PhD Candidate at TalTech University in Tallinn, Estonia, elaborating the impact of Smart Specialisation on the Blue Economy of the Baltic Sea Area.

ORCID ID: orcid.org/0000-0002-6048-1198

Prof. Dr. Gunnar PRAUSE is a professor at the Tallinn School of Economics and Business Administration at Tallinn University of Technology (TU) Tallinn in Estonia as well as at Hochschule Wismar, University of Applied Sciences: Technology, Business and Design in Wismar, Germany. Professor Gunnar Prause has published widely internationally and has many years of experience in carrying out national and European (research) projects.

ORCID ID: orcid.org/0000-0002-3293-1331

Make your research more visible, join the Twitter account of ENTREPRENEURSHIP AND SUSTAINABILITY ISSUES: @Entrepr69728810

Copyright (C) 2021 by author(s) and VsI Entrepreneurship and Sustainability Center

This work is licensed under the Creative Commons Attribution International License (CC BY).

http://creativecommons.org/licenses/by/4.0/

cC) (7) Open Access 